\title{
THE ART OF THE OLD MASTERS - TABLEWARE OF THE ANABAPTISTS AND HABAN FAIENCE FROM WESTERN SLOVAKIA IN THE COLLECTIONS OF THE AUSTRIAN MUSEUM OF FOLK LIFE AND FOLK ART IN VIENNA
}

\author{
Claudia Peschel-Wacha \\ Austrian Museum of Folk Life and Folk Art \\ Laudongasse 15-19, 1080 Wien, Austria \\ E-mail: claudia.peschel-wacha@volkskundemuseum.at
}

\begin{abstract}
The Austrian Museum of Folk Life and Folk Art in Vienna was founded in 1895. From the beginning, ceramics were collected. Today, the ceramic collections include about 15,000 objects, of which more than 300 are faiences most probably originating from the west of Slovakia. About 70 of these are from the $17^{\text {th }}$ century and about 80 from the $18^{\text {th }}$ century. Many of the objects entered the collections in the early years of the museum through donations and purchases. An important patron was the art historian Alfred Ritter Walcher von Molthein (1867-1928). He was one of the $19^{\text {th }}$ century researchers and collectors who started the Haban myth about the Hutterites.

Between 1974 and 2008, the Austrian Museum of Folk Life and Folk Art had a branch museum in Burgenland, the Ethnographic Museum in Kittsee Castle. During restoration work on the castle, shards were found that are known as the Kittseer Kellerfund (Kittsee cellar find)

Keywords: Haban, Hutterite faience, Kittseer Kellerfund, Slovakian ceramics, Slovak-Austrian cross-border cooperation programme, Falkenstein
\end{abstract}

\section{INTRODUCTION}

On Sunday, June 19, 2011, at the castle ruin Falkenstein in northern Lower Austria (Fig. 1) there was a memorable event. It commemorated a terrible incident that had happened 472 years earlier in the nearby town, Steinebrunn. In the night of December $6^{\text {th }} 1539$, the king's soldiers attacked a Hutterite communal farm, a 'Bruderhof', and took about 150 Anabaptists to the prison of castle Falkenstein into prison (EICHINGER 2009: 109 and 25). The captivity lasted for weeks in what is still called the Anabaptist crypt. During this time they were urged to recant their faith, but they refused. After a moving farewell scene, 90 male Anabaptist prisoners were marched off to Triest where they were condemned to the galleys. Students at the HTL Mödling (a technical school) recreated a galley which is now on display in the courtyard of the ruin in their memory. 


\section{NEW MEMORIES ABOUT THE ANABAPTISTS}

The Anabaptist crypt was opened as a memorial and an information centre at the castle ruin Falkenstein. At the opening ceremony all listened intently to the retelling of the persecutions that this religious group went through. The visitors included descendants of Anabaptist families in Lower Austria and neighbouring countries as well as representatives of the free churches. These churches are in the lineage of the Anabaptist movement and their members make up a third of all the Christians in the world today (EICHINGER 2009: 132). An exhibit on the Anabaptists was opened in a cottage in the Lower Austrian Open Air Museum Niedersulz in 2008 (Fig. 2). The large number of guests who have visited it since then shows that there is substantial interest in the efforts of the 'Hutterischer Geschichtsverein' (Society for Hutterite History) to research the Anabaptist movement in Lower Austria. At castle ruin Falkenstein, local events during time of the religious persecutions are brought to mind through the impressive installations. There is a special aura around these physical witnesses to the Anabaptist communities. They were known for their high quality craft products - and among those particularly for their faience pottery.

\section{THE ANABAPTIST MOVEMENT}

The Anabaptist movement is the third wing of the Reformation, also called the 'radical reformation'. The Anabaptists were of the opinion that the only baptisms that met the requirements of the New Testament were those that were desired by mature Christians and were carried out on them. This had the result that they celled them 'Wiedertäufer' (rebaptizers) or 'Anabaptists' (EICHINGER 2009: 34). One large group in this movement, that still exists today, was the Hutterites, also known as 'Hutterite brethren' or 'Hutterite Baptists'. They were followers of Jakob Hutter, a Tyrolean preacher from Pustertal, who was also quite successful in Moravia. They lived in communes, the so called 'Bruderhofs'. Hutter was burned to death in Innsbruck on February 25, 1536.

Large numbers of Anabaptists came to Moravia starting in 1526, and from 1546 they also settled in the neighbouring border areas of Lower Austria and Western and Northern Hungary, the area that is now Slovakia (KALESNÝ 1976: 22), first in Zahorie, and later east of the Little Carpathians. They were excellent craft workers and their potters knew the secret of pure white tin oxide glazes. It is still not clear how this 'Stile bianchi' came from Italy, and specifically from Faenza, over the Alps to Switzerland, Tyrol and Southern Germany and then on to Moravia and Western Slovakia (BAUER 1985: 8-9). The faience pottery, so similar to porcelain, was in high demand, and the Anabaptists copied both form and decoration. They used a thin layer of white, blue or even yellow background glaze and decorated it with delicate painting. These simple, but fine faience objects were able to both express the austere faith of the Anabaptists, and also agree with the taste of the main customers, who were in the nobility. From this period we have some items that are covered with a white glaze and no decoration. (ÖMV/15.920, EMK/1104) ${ }^{1}$ The Ana-

\footnotetext{
${ }^{1}$ ÖMV = Österreichisches Museum für Volkskunde (Austrian Museum of Folk Life and Folk Art, EMK $=$ Ethnographisches Museum Schloss Kittsee (Ethnographic Museum in Kittsee Castle).
} 
baptists were not part of the guilds and were not tied by the rules of local craft organizations. They achieved prosperity with their fine products and were seen as competition by the local potters.

After the Battle of White Mountain, the path was clear for the counterreformation. In 1621, the Anabaptists had to leave Moravia for good and fled into Western and Northern Hungary, into what is now Slovakia and into Transylvania (KALINOví 2005: 15). The most important communes were in Szobotist (Sobotište, Slovakia) and Nagylévárd (Vel'ké Leváre, Slovakia). Nobles such as Batthyány, Esterházy, Nádasdy, Pállfy and Liechtenstein were important customers. They also did their best to protect the communities that were in their territories.

\section{ON THE TERMINOLOGY OF 'HABAN FAIENCE'}

In the $19^{\text {th }}$ century a myth developed around this term, and to this day it is used for a certain type of faience pottery that has been made in Moravia, Hungary, Western Slovakia and Transylvania since the sixteenth century. During a symposium about the Hutterite Anabaptists in Germany in 1981, Kurt L. Rein suggested breaking this down in a way that fits their history quite well (REIN 1985: 94). According to this chronology, the faience can be divided up in this way (all years are approximate): In the 16th century until 1622 we should speak of Anabaptist ceramics or early Hutterite ceramics. Between 1622 and 1685 we call it Hutterite whiteware and between 1685 and 1730 - Haban Faience.

Haban is actually the name for those Anabaptists, who converted to Catholicism. This also meant that they were no longer tied to the strict rules about decoration that were typical of the Anabaptists. From 1685, the Anabaptist communities in the whole Hungarian kingdom broke up. Maybe it was the local Slovakian population that gave this name to those who lived in the communes. The Haban expert František Kalesný brings several explanations for the expression "Habaner". The name can also derive from the Hebrew habanim (the true children of God) as the Anabaptists called themselves. Ha-banim became habáni when repeated by their Slovakian neighbours. This entered the German language as Habaner. 'Haban' could also derive from zhabané majetky, which would refer to the Anabaptists being driven out of Moravia after the 30 Years War (KALESNÝ 1981: 8-12). Another possible derivation would be directly from the German Haushaben (to have a house) (PASTIERIKOVÁ 2005: 116).

It is best to only use the term 'Haban Ceramics' for objects made after the late 17th century. It is from this time that the faience ceramics started to become Slovakian. In the 18th century, we move on to the late Haban period and in the 19th century to the postHaban period. Influences from the faience centre in Holics (Holič, Slovakia) and customer demand from the very religious population combined to make Szobotist, Dejte (Dechtice, Slovakia) and Stomfa (Stupava, Slovakia) develop into centres of 'Folk Maiolica'.

In 1733, Emperor Charles VI ordered that children could only be baptized by Roman Catholic priests. The Brethren had to obey or emigrate (EICHINGER 2009: 26; BRÜCKLER 2004: 127). When Maria Teresia became ruler, she demanded strict loyalty 
to the Catholic Church. She permitted the Jesuits to use force to 'convert' Lutherans, Reformed Christians and Hutterites (Horst 1985: 41). The surrender of the commune in Szobotist in 1763 was the end of the Hutterite communities in the Habsburg territories.

\section{ABOUT THE COLLECTION OF THE AUSTRIAN MUSEUM OF FOLK LIFE AND FOLK ART IN VIENNA}

In 1961, the ethnologist and ceramic expert Adolf Mais (1914-1982) put an exhibition together called 'Haban dishes - Ceramics of the late Anabaptists' in the Austrian Museum of Folk Life and Folk Art in Vienna. Although the pieces from the Kittseer Kellerfund had not yet been found, Mais was able to put together a group of 47 faience pieces from the period from 1600-1750 (MAIs 1961a). His show began with a bowl from Faenza, as a didactic example labelled 'connections to the Italian region' (MAIs 1961a: 129). It ended with a vase from Stomfa made by Ján Kostka (the younger) from a copy of an older work made in 1760 by Ján Putz (PIšútová 1981: 340) on which we can read: 'Von Gott ist ales' (Everything comes from God) (ÖMV/83.381, Fig. 3). With this piece, Mais wanted to 'emphasize that both the ceramic tradition and the God-fearing attitude lived on in the Catholic descendants of the Anabaptists' (MaIs 1961a: 130).

When choosing the pieces for the exhibition, Mais was able to make his decisions based not only on an outstanding collection of available pieces, but also on earlier studies. Michael Haberlandt, founder and director of the museum, had set up the first classification scheme in his book Österreichische Volkskunst (Austrian Folk Art), which was published in 1911 (HaBerlandt 1911: Textband 93-103, Tafelband Tafel 54-60). His first group was of melon-shaped jugs and wide-rimmed dishes with the typical tulip and forget-me-not designs arranged with vines, arabesques and bouquets. These objects are very similar, both in form and in their delicate decor, to the Swiss faience pieces created in Winterthur around 1600 (HABERLANDT 1911: Textband 97. Figs. 29, 30). Another group is made up of pieces with blue or yellow ground and delicate tulip, lily of the valley and scale designs. Another group is of pure white faience pieces: wide-rimmed dishes, a bowl with pierced rims, divided platters, squat pitchers, all either with heraldic devices or the initials of the customer and the year in a green wreath of leaves. Apart from this type of tableware meant for noble and well-off bourgeois families we also find a group of products that were painted with craft insignia for lower class owners, and guild members (HABERLANDT 1911: Textband 99). The oldest jug of this kind is the 'Bäckerkrug' (Baker's jug) made in 1660. (ÖMV/24.147, Fig. 4) (HABERLANDT 1911: 99). This craft pitcher tradition continues into the 19th century. In Haberlandt's scene, a fourth group starts at about 1680 and is made up mostly of dishes with a wide rim covered in dense blue decor and interspersed yellow animal figures. This group also includes the decors with palmettes and chinoiserie, sometimes on blue wave lines. 


\section{RENAISSANCE STYLE DESIGNS}

There is no catalogue for the 1961 exhibition. We can assume that this first exhibition included the oldest dated Anabaptist piece in the collection of the ÖMV, a footed bowl (tazza) (ÖMV/36.030, Fig. 5) It was made in Sobotište in 1629. Similar pieces are found in the collection of the Moravské zemské muzeum (Moravian Museum) in Brno, Czech Republic (ÖMV/ 20.408) and the Museo internazionale delle ceramiche Faenza, Italy (ÖMV/ 21309/c) (Kalinová 2004: 55, Abb. 11; PAJer 2006: 148-151). The object in Vienna is one of two pieces that were originally owned by Alfred Walcher von Molthein (1867-1928), one of the first collectors and experts on 'Haban ceramics'2. In 1917, his ceramics collection was auctioned off at the Viennese Art Dealer Wawra. This piece and a ring bottle (ÖMV/35.992, Fig. 6) were bought by Michael Haberlandt (Wawra 1917: 7. n. 40, 8. n. 52). Until the middle of the 17th century, the typical simple designs of the Anabaptist tableware showed delicate Renaissance-style flowers surrounded by a blue double line. These reflected the influence of the strict orders of the community (TVRDY 1912: 207).

This tankard made in 1640 (ÖMV/26.136, Fig. 7) is an individual piece, and is $35 \mathrm{~cm}$ high. Jiři Pajer suggests Szobotist as a possible provenance and Hans Nüller as perhaps the Haban-Hutterite potter. ${ }^{3}$ Both the form and decoration of a jug with diagonal ribs from 1668 (ÖMV/31.527, Fig. 8) suggest a comparison to a find in the canon's house in Časta (Cseszte, Hungary) (BORECKÁ 2010: 10). Shards of a similar container were found with the date of 1663. Other similar pieces are a bowl with side handles and tulip decor from the Kittseer Kellerfund and another piece from Časta. ${ }^{4}$ (EMK/1115)

\section{THE KITTSEER KELLERFUND (KITTSEE CELLAR FIND)}

Between 1974 and 2008, Kittsee Castle on the border with Slovakia and Hungary, quite near Bratislava (Pozsony, Pressburg, Hungary) housed an ethnographic museum. This branch museum of the Austrian Museum of Folk Life and Folk Art in Vienna was the result of an initiative of the ceramic expert Adolf Mais. Here, there was the possibility of exhibiting the large collection of items from Southeast Europe. During the renovations in 1973, a lucky find was made. In a walled up cellar under the kitchen area there were a large number of shards. From the $120 \mathrm{~kg}$ of shards, it was possible to reconstruct about 70 containers (MAIs 1981a: 9). Among all these pieces of pottery there were at least 10 faience objects. Both the place and time of their use were therefore known. For decades these pieces were on display as the Kittseer Kellerfund in the permanent exhibit of the Ethnographisches Museum Schloss Kittsee (Ethnographic Museum Kittsee Castle). They were also described and illustrated in many publications (HoRvATH 2005: 69, 70; RÉTI 2007: 1; KaLINOvÁ 2004: 37, 51, 81). The historical background is that the Anabaptists founded a settlement in Köpcsény (Kittsee, Austria) in 1622/23 under Freiherrn Ferenc

\footnotetext{
${ }^{2}$ See the chapter Heroes \& Victims: Alfred Walcher von Molthein in HoRvath 2005: 27f.

${ }^{3}$ See objects of comparison: Horvath 2005: 94, Figs. D and E on page 112.

${ }^{4}$ Cf. Peschel-Wacha 2011: 84, Fig 8 with Borecká 2010: 11.
} 
Listy (who is also said to have been an advisor to Prince Bethlen Gabor in Transylvania). This Anabaptist community is supposed to have existed until 1647 (FASSBINDER-BRÜCKLER 2004b: 80). Listy's descendant, Count Johann Listy, started building the baroque palace at Köpcsény in 1668.

When the cellar was walled up in 1705, it was full of rubble and garbage. The Esterházy had the palace rebuilt between 1730 and 1740 . In the $19^{\text {th }}$ century, it was acquired by the Batthyány family. Brigitte Fassbinder-Brückler assumes that some of the pottery from the Kittseer Kellerfund was manufactured on the premises (FASSBINDER-BRÜCKLER 2004a: 37). On the other hand, there is a break of more than 20 years between the end of the Anabaptist presence and the building of the palace. Adolf Mais, in his publication about the Kittseer Kellerfund suggests that the faience pieces could have been bought at a local market, or else the cities Pressburg and Vienna could have been the place where they were purchased (MAIs 1981a: 16-17).

\section{TABLEWARE FROM THE ANABAPTISTS}

Other containers from the 17th century were also part of the Kittseer Kellerfund: Round belly jugs with a central fantasy flower from the time around 1650 (EMK/1120) and 1680 (EMK/1109) as well as jugs with their surface divided into picture stripes, with arched pyramid borders (EMK/1103, Fig. 9). ${ }^{5}$

A separate group is made up of faiences with marbled glaze. The ceramic artist Ignác Bizmayer has shards with a similar marbled glaze that he found when digging at the 'Bruderhof' at Košolná. Another clue which leads to Transylvania (KLUSCH 1985: 136. pic. 7). Perhaps this marbled glaze was a modern decor that was used in various workshops in the time between 1680 and 1705 . The museum houses lovely and unusual examples both from the Kittseer Kellerfund and from the Vienna collections. This includes simply made pitchers (EMK/1121 and ÖMV/30.683) a small pitcher (ÖMV/18.854), others with architectural depictions and yellow birds (EMK/1111, EMK/1114) and jumping hares (EMK/1112). ${ }^{6}$ The jug form is unusual (oNr/2.563). ${ }^{7}$

Flat pieces include a dish with yellow and green scattered designs with manganesecoloured contours (ÖMV/18.929). Another unusual example is a footed plate with a curved edge (ÖMV/27.919, Fig. 10). Houses, towers, hares, insects and birds swirl around on a blue background. Could they perhaps be a depiction of Noah's flood? A plain blue marbled dish has the number ÖMV/27.044. Other single pieces of Anabaptist origin are a tile of the Vlčkovce type (former Farkašín, Hungarian Farkashida, oNr/4.452), a cask with green stripes (oNr/4490) and a fluted bowl dated 1707 with a lily of the valley design (ÖMV/27.655, Fig. 11). The classic decors of the 17th century include wreaths of leaves, liverleaf flowers, tulips, pomegranates and later also pyramids of arches, for example on the pitcher with pewter lid dated 1678 (ÖMV/31.526) or on a pannonian 'Plutzer' dated

\footnotetext{
${ }^{5}$ See objects of comparison: HoRvath 2005: 100, catalogue number 5.

${ }^{6}$ See objects of comparison: HoRvath 2005: 258, catalogue number 88.

${ }^{7}$ Pictures of marbled objects in the article Peschel-Wacha 2007.
} 
1698 (ÖMV/29.521) and on a dish with pomegranates dated 1689 (ÖMV/29.286). The handle of a jug from 1654 has an unusual form. Its end is raised semicircle and decorated by a sunflower (ÖMV/44.071, Fig. 12). The inscription is an appeal ("Mahnspruch") typical of the Anabaptists: "Merkh aof jonger Heldt Goete Taag schene Jongfraven Kostn gelt." (Be aware young hero that beautiful virgins cost money) (MAIs 1961b: 169). Besides the footed bowl with perforated sides, fluted dishes are a typical late Renaissance form from Northern Italy (LANGER 1988: 41). They became a popular Haban product, for example a heraldic oval fluted platter on four feet with lily of the valley. (ÖMV/26.835, Fig. 13) Six-sided bottles were also part of their repertoire, such as the one from 1711 that shows a double cross with the instruments of the passion, a castle, and an eagle with a sword. (ÖMV/25.263, Fig. 14)

A water container from 1703 is another unusual piece. (ÖMV/27.660, Fig. 15) It was bought in 1911 from a Viennese antiques dealer and was on display in Kittsee. On the display side there is a yellow heraldic motif with a pelican wounding itself to feed its young, surrounded by Renaissance ornaments, crowned by a hand holding a sabre or a sword that is reminiscent of a market sword. This could be a depiction of Christian symbolism and iconography, as the image of the pelican offering its blood was a symbol for Jesus Christ. We also find the pelican in the crest of the Batthyány family, along with a cave in a rock with a lion that has a Turkish sabre in its throat. ${ }^{8}$ The water container probably was somehow associated with the Batthyánys. A comparable piece is in the Hungarian National Museum (HoRvath 2005: 283).

\section{THE HABAN PERIOD}

In the second half of the 17 th century soup started to appear as a new dish on middle class menus. This required a new type of tableware: the wide rimmed dish starts to have a deeper depression (Ridovics 2008). Along with the shape, the decor also changed. Now animals and people were also depicted. Classical Haban faience style is made up of several picture stripes that are edged with blue double lines and surrounded by decorative borders. A bottle with a pewter screw top, flattened on four sides (ÖMV/23.903). A slender jug with a picture of a stork (ÖMV/14.085). A dish with classical decor and blue palmette design (ÖMV/18.916). The classical three flowers on the rim of a dish are joined by a fish, a crayfish and a bird. A green wreath of leaves around the date 1710 is bowl itself (ÖMV/26.529, Fig. 16). The stylised palmettes are taken from the fashionable Chinoiserie. A writing set (inkstand) shows the dark blue decoration in profuse palmette style (ÖMV/19.402). Also a dish bought in 1908 from the collection of Lázar Schneider in Sopron (ÖMV/19.282) and another with blue painting for SEWERIN SPILKA 1720 (ÖMV/23.791). The dark blue palmettes are strongly in evidence in the cylindrical pitcher with a pewter lid, about 1720 (ÖMV/41.442) and in a dish (ÖMV/19.282) and the one with a lamb in a wreath of leaves, dated 1720 (ÖMV/23.045). There is only one dish with the Habsburg double eagle in the centre of the well, dated 1719, surrounded with a mixture of yellow tulips and blue palmettes on the rim (ÖMV/5.933, Fig. 17).

\footnotetext{
${ }^{8}$ http://de.wikipedia.org/wiki/Batthy\%C3\%A1ny (last accessed on $3^{\text {rd }}$ of January 2013).
} 


\section{INNOVATION FROM HOLLAND OR FROM CURRENT TRENDS}

In 1665, two of the brethren from Sobotište visited the Dutch communities of the Hutterites and asked them for economic aid (HoRst 1985: 38f). In the process they came into contact with Delft faience. Some researchers assume that this was the impulse for the new decors, the elaborate blue and white pottery and the chinoiserie (KALINOVÁ 2004: 53, $60)$. After the spare decor from the beginning of the $17^{\text {th }}$ century, towards the end of the century an opulent blue and white pottery developed that negated the picture fields and sectors and dissolved the previous direction of the decor into the centres of the dishes. Horvath and Kristinkovich are not convinced that the Delft influence was decisive and refer to comparable objects from Frankfurt-Hanau, England and France (HoRvath 2005: pictures n. 32, 35, 37, 38). These changes are perhaps best explained in this way: Once their strict communities were dissolved for economic reasons, the brethren were open to innovation and went with the fashions. This is a group of faiences in 'camaieu bleu', in various shades of blue, painted with a fine brush as a sketch. A dish (ÖMV/2.536, Fig. 18) shows five architectural motifs facing the viewer. Four are on the rim and one in the well. There are houses on hills. In between oversized birds and flowers fill the spaces. There are also cross shaped spots, called 'insects', dots formed into flowers and individual small dots. Further examples are so-called 'cardinal's hat' dishes (ÖMV/18.041), then there are dishes with flat bases (ÖMV/44.081 and ÖMV/45.286 dated 1707), and a jug with pewter attachments, filled with architectural motifs (ÖMV/35.989). Wide rims of large dishes were painted with carpenter and cartwright symbols next to pipe-smoking men as blue and white pottery in the Dutch manner. This in an indication of the Dutch influence at that time (signed MK1711, ÖMV/7.809, Fig. 19).

\section{NEW CUSTOMERS}

From the second half of the 17th century, we see the traces of new customers on the faience ware. Now middle class customers are ordering the coveted faiences and Guild members are proud to have their trade symbols painted on them. We have already discussed baker Johannes Rath's jug from 1660 (HABERLANDT 1911). Boot maker Johones Hortnyc had a dish made in $1699^{9}$ (ÖMV/18.917). There are also examples for shoemakers, weavers, butchers and tailors (a dish with a deep well and wide rim from 1698 ÖMV/31.525, Fig. 20). These pot makers were making items for guilds at this time, although they did not found the first pot maker guilds until a century later, in the late $18^{\text {th }}$ century, for example in 1770 in Holics (GRANEC 2010: 11f).

\footnotetext{
${ }^{9}$ There is a similar object in the Museum of Applied Arts in Budapest. LAYER 1927: 11.
} 


\section{THE ODLER WORKSHOP IN DECHTICE}

A group of dishes can be attributed to the Odler workshop in Dechtice. They have a typical style which includes a mostly blue band of decoration on the rim, with densely set plant motifs overlapping each other, architectural features and pictures of animals (birds, hares, deer, crayfish, an owl...) $)^{10}$ The museum has six of these dishes. (ÖMV/19.496, Fig. 21, ÖMV/19.892, ÖMV/22.603, ÖMV/41.507, ÖMV/41.508, ÖMV/44.333)

\section{THE LATE HABAN AND POST-HABAN PERIOD}

After 1700, new motifs appear. Scenes from a topsy-turvy world are depicted in the underglaze colours blue, green, yellow and brown. The traditional elements are mixed with new ones and become more concrete (for example ÖMV/44.920, Fig. 22). Some may be scenes from fables such as those of La Fontaine. ${ }^{11}$ After 1730, the surfaces become even more filled with decoration. The wreath of leaves grows into a major element in the design and becomes integrated with heraldic ornaments and lions (for example ÖMV/28.871). The customers now include even the lower classes. A shepherd or farmer would order a commemorative piece to remind him and his family of a special event in their lives. They and their symbols are immortalized in clay: the shepherd with his flock, the farmer working in his fields, the vintner with his grapes and tools (PeSCHEL-WACHA 2005: 371-392).

\section{THE "OWL"}

A typical Slovakian form of container is the 'sova' (Slovakian word for owl). Herrman Landsfeld lists this special form in his table among the West Slovakian jugs (staré tvary vysokého riadu) in 1931 (KALINOVÁ 2010: 110). The name refers to the German manufacturers, the 'Euler'. So was celled the combined guild of the Kannen- und Krugbäcker (pitcher and jug bakers) in German Westerwald. ${ }^{12}$ This name goes back to the Latin 'olla' for pot (KLEINE 1992: 29). This expression probably came into Slovakia with immigrant potters and was transferred to this type of pot. The 'Plutzerkrug', called 'Eule' (German for owl) or 'sova', is a jug with a covering and a narrow opening. The museum has several examples made in the 19th century. They all come from the West Slovakian region (see for example ÖMV/8.208 from Sobotište, Fig. 23)

\footnotetext{
${ }^{10}$ RÉTI 2007: catalog number 89-98.

${ }^{11}$ I am grateful to my colleague Francová for this suggestion. See also Francová 2011.

12 Keramikmuseum Westerwald 1990: 88: "Ullenowen" = Eulerofen and page 22: "Eulereien" = Steinzeugtöpfereien.
} 


\section{THE HABAN MYTH}

The Haban myth developed in the $19^{\text {th }}$ century. Private collectors and institutions built their collections. ${ }^{13}$ The Austrian Museum of Folk Life and Folk Art in Vienna, founded in 1894 by a museum association, made a point of collecting Haban ceramics. Since the closure of the Ethnographic Museum Kittsee Castle there have been several inquiries about the Kittseer Kellerfund and Haban faiences.

Thanks to the support from the bilateral programme of the European Union (EU) 'creating the future', a Slovak-Austrian cross-border cooperation programme 2007-2013 (project TRA-KER), it was possible to study and re-catalogue the complete inventory of western Slovakian ceramics in 2011 and 2012 with the help of the Slovakian ethnologist Marta Pastieriková. ${ }^{14}$ From May to August 2012, a selection of pieces were shown at the first exhibition in the newly constructed Museum of the Slovak Ceramic Sculpture in Modra (Slovakia) entitled: Ceramic Heritage - Western Slovakian Faience from the Austrian Museum of Folk Life and Folk Art. ${ }^{15}$

Thanks to the support programme of the European Union (EU) 'creating the future', a Slovak-Austrian cross-border cooperation programme 2007-2013, it has been possible to prepare this collection in the years 2011 and 2012 and to display it in the Museum of the Slovak Ceramic Sculpture in Modra (Slovakia) in the first exhibition named: Ceramic Heritage - Western Slovakian Faience from the Austrian Museum of Folk Life and Folk Art in Vienna.

\section{LITERATURE}

BAUER, Ingolf

1985: Das Symposion „Die Hutterischen Täufer. Geschichtlicher Hintergrund und handwerkliche Leistung." [The Symposium “The Hutterite Baptist. Historical background and manual power"]. In: Die Hutterischen Täufer. Geschichtlicher Hintergrund und handwerkliche Leistung. Ed. by Bayerischen Nationalmuseum München. Bolanden 1985, 7-12.

Borecké, Eva

2010: Killyho kúria v Častej. (Manor House Killy in Častá). Pamiatky a múzeá č. 4/2010, 8-11.

BRÜCKLER, Theodor

2004: Kulturgeschichtliche Bedeutung und Nachwirken der Hutterer [The Cultural Historical Importance and the Aftermath of the Hutterite]. In: Alena KALINOvÁ - Brigitte FAssBInDER-BRÜCKLER v Theodor BRÜCKLER: Täufer - Hutterer - Habaner. Geschichte, Siedlungen, Keramik in Südmähren, Westslowakei und Niederösterreich. Hollabrunn 2004, 87-130.

13 See the chapter Heroes \& Victims: Alfred Walcher von Molthein in Horvath 2005: 27-28.

14 The Moravian Anabaptist faiences in the collection of the Museum of Folk Life and Folk Art are described in the article of KaLINOVÁ: 2011. see page $407 \mathrm{ff}$.

${ }^{15}$ No catalogue was published for this exhibition. The curator reported about the displayed objects in her symposium report. This article goes back to a written version of a lecture held during an international symposium in Modra, Slovakia in 2011. It has been printed in Slovakian. See Peschel-Wacha 2011. For this publication modifications were done in the text and in the selection of the pictures. The English translation of this article is made by Martha Jeanne Barton. 
EICHINGER, Reinhold - EnZENBERGER, Josef F.

2009: The Anabaptist Museum in Niedersulz. (Täufermuseum Niedersulz.) Museumsführer. Hamburg 2009.

FASSBINDER-BRÜCKLER, Brigitte

2004a: „Brüderische“ Keramik in Österreich mit Schwerpunkt auf Niederösterreich [Anabaptist ceramics in Austria focused on Lower Austria]. In: Alena Kalinová, Brigitte FassBinder-Brückler, Theodor BRÜCKLER: Täufer - Hutterer - Habaner. Geschichte, Siedlungen, Keramik in Südmähren, Westslowakei und Niederösterreich. Hollabrunn 2004, 29-45.

2004b: „Brüderische“ Siedlungen, ihre Anlage und ihre Architektur [Anabaptist Communities, Their Site and Architecture]. In: Alena KalinovÁ, Brigitte FASSBINDER-BRÜCKLER, Theodor BRÜCKLER: Täufer - Hutterer-Habaner. Geschichte, Siedlungen, Keramik in Südmähren, Westslowakei und Niederösterreich. Hollabrunn 2004, 65-86.

FrancovÁ, Zuzana

2011: Habánske pamiatky v zbierkach Múzea mesta Bratislavy [Haban Objects in the Collections of the Bratislava City Museum]. In: Habáni a habánska keramika. Zborník z medzinárodného odborného seminára, konaného 3. septembra 2011 v Modre. Hg. vom Slowakischen Nationalmuseum - Múzeum Ludovíta Štúra v Modre 2011, 15-28.

GrANEC, Ján

2010: Výroba a predaj keramiky v súčasnosti. Profil keramikára z Pezinka. [Manufacturing and Sale of Ceramics at Present Time. Profile of a potter from Pezinok]. Bakkalaureatsarbeit der Univerzita sv. Cyrila a Metoda in Trnava 2010.

Haberlandt, Michael

1911: Haberlandt: Österreichische Volkskunst [Austrian Folk Art]. Textband und Tafelband. Wien.

Horst, Irvin B.

1985: Horst: Die Hilfe holländischer Doopsgezinden an die Hutterischen Brüder in der Slowakei im 17. und 18. Jahrhundert. [The Aid of the Mennonite Church in the Netherlands to the Hutterites in Slovakia in the $17^{\text {th }}$ and the $18^{\text {th }}$ Centuries]. In: Die Hutterischen Täufer. Geschichtlicher Hintergrund und handwerkliche Leistung. Ed. by Bayerischen Nationalmuseum München. Bolanden 1985, 38-44.

Horvath, J. Eugene - Krisztinkovich, Maria H.

2005: A History of Haban Ceramics. A private view. A Canadian Collection of Hungarica. Vancouver .

KaLESNÝ, František

1976: Habánska keramika na slovensku [Haban Ceramics in Slovakia]. Katalog. Bratislava 1976.

1981: Habáni na slovensku [The Haban in Slovakia]. Tatran 1981.

KaLinovÁ, Alena

2005: Nejstarší doklady lidové fajánse z moravy [The Eldest Documents of the Anabaptists in Moravia]. In: Folia ethnographica 39. Supplementum ad Acta Musei Moraviae. Scientiae soziales XC, Brno 2005, 3-15.

2010: The Ceramics Collection in the Ethnographic Institute of the Moravian Museum. In: Keramische Begegnungen: Sachsen - Schlesien - Böhmen. Beiträge zum 42. Internationalen Symposium Keramikforschung des Arbeitskreises für Keramikforschung vom 21. bis zum 25. September 2009 in Görlitz (D). Raeren 2010, 107-118.

2011: Ceramics from Moravia in the Collection of Österreichisches Museum für Volkskunde in Vienna. In: Vestiges of the Past. Science in the Moravian Museum on the threshold of the third millenium. Moravské zemské muzeum Brno, 2011, 399-422.

KalinovÁ, Alena - FASSBINDER-BRÜCKLER, Brigitte - BRÜCKLER, Theodor

2004: Täufer-Hutterer - Habaner. Geschichte, Siedlungen, Keramik in Südmähren, Westslowakei und Niederösterreich. [Anabaptist - Hutterite - Haban. History, community, ceramics in South Moravia, Western Slovakia and Lower Austria.] Hollabrunn 2004.

Keramikmuseum WesterWald

1990: Keramikmuseum Westerwald. Deutsche Sammlung für historische und zeitgenössische Keramik Höhr-Grenzhausen [Museum for Ceramics Westerwald. German collection for historical and contemporary ceramics]. In: Museum (Museumsführer). Braunschweig 1990. 
KLEINE, Dorette

1992: Keramikmuseum Frechen. [The Frechen Museum for Ceramics]. In: Museum (Museumsführer). Frechen.

KLuSCH, Horst

1985: Neue Forschungsergebnisse zu dem Thema Habaner in Siebenbürgen [New Research Results about the Habans in Transylvania]. In: Die Hutterischen Täufer. Geschichtlicher Hintergrund und handwerkliche Leistung. Ed. by Bayerischen Nationalmuseum München. Bolanden 1985, 130-139.

LANGER, Hermann

1988: Österreichische Fayencen [Austrian Faiencen]. München 1988.

LAYER, Karl

1927: Oberungarische Habanen Keramik [Haban Ceramics in Upper Hungary]. Veröffentlichung des Königlichen Ungarischen Kunstgewerbemuseums in Budapest. Berlin, Leipzig und Wien, Friedrich

MaIs, Adolf Ernst Hübsch Verlag 1927.

1961a: Die Ausstellung „Habaner Geschirr - Keramik der späten Wiedertäufer“ im Österreichischen Museum für Volkskunde [The Exhibition "Haban Tableware - Ceramics of the Late Anabaptists" in the Austrian Museum of Folk Life and Folk Art]. In: Mitteilungsblatt der Museen Österreichs. 10. Jg., Wien 1961, Heft 7/8, 128-132.

1961b: Literarisches und Graphisches auf Habaner Keramiken [Literary and Graphic Items on Haban Ceramics]. In: Österreichische Zeitschrift für Volkskunde. NS Bd XV, GS Bd 61, Wien: Verein für Volkskunde 1961, 149-197.

1981: Der Kellerfund von Kittsee [Kittsee Cellar Find]. Kittsee 1981.

PAJER, Jiři

2006: Studie o novokrstencich [Surveys on the Anabaptists]. Straznice: ETNOS, 2006.

PAstierikovì, Marta

2005: Die Keramiksammlung des Slowakischen Nationalmuseums in Martin [The Ceramics Collection in the Slovak National Museum in Martin]. In: Keramik ${ }^{3}$ - gebrannte Idylle. Typen/Regionen/Museen. Katalog zur Ausstellung. Mit Beiträgen von Marta Pastieriková, Péter Illés und einem Katalogteil von Claudia Peschel-Wacha. Wien/Kittsee 2005, 106-139.

Peschel-Wacha, Claudia

2005: Hirtenidyllen - Stereotypen auf slowakischen Fayencen [The Shepherds Idyll. Stereotypes on Slovak Faiences]. In: ENDRES, Werner - GRIESHOFER, Franz (eds): Keramik als Zeichen regionaler Identität. Beiträge des 36. Internationalen Hafnerei-Symposiums des Arbeitskreises für Keramikforschung vom 21. bis 26. 9. 2003 in Kittsee (= Kittseer Schriften zur Volkskunde, Band 16). Wien/Kittsee 2005, 371-392.

2007: „Marmorierte“ Fayencen aus der Barockzeit. Forschungen rund um diese Dekorart anhand von Beispielen aus dem Österreichischen Museum für Volkskunde in Wien und dem Kittseer Kellerfund [Marbled Faiences from the Baroque Era. Research on this kind of decoration on the basis of examples in the Austrian Museum of Folk Life and Folk Art and the Kittseer cellar find]. In: Keramische Oberflächen und ihre Gestaltung. Beiträge zum 39. Internationalen Hafnereisymposium des Arbeitskreises für Keramikforschung Hermannstadt (RO), 2006. Sibiu 2007, 11-16.

2011: Umenie starých majstrov - bratský riad a habánska fajansa v inventári Rakúskeho národopisného múzea vo Viedni [The Virtuosity of the Old Masters. Anabaptist dishes and Haban faiences in the collections of the Austrian Museum of Folk Life and Folk Art in Vienna]. In: Habáni a habánska keramika. Zborník z medzinárodného odborného seminára, konaného 3. septembra 2011 v Modre. Ed. by Slowakischen Nationalmuseum - Múzeum L'udovíta Štúra v Modre 2011, 79-95.

PIšútovÁ, Irena

1981: Fayencen [Faience Ware]. Bratislava 1981.

Rein, Kurt L.

1985: Rein: Zur Frage der „Habaner“, „Hutterer“ und ihrer Keramik [About the Habans - Hutterites and Their Ceramics]. In: Die Hutterischen Täufer. Geschichtlicher Hintergrund und handwerkliche Leistung. Ed. by Bayerischen Nationalmuseum München. Bolanden 1985, 93-98. 
RÉTI, László

2007: Habán mitosz 1593-1738. Magyar magángyüjtemények kincsei. Haban myth 1593-1738. Treasures from Hungarian Private Collections. Katalog zur gleichnamigen Ausstellung im Museum of Applied Arts, Budapest, 21 May-25 November 2007.

Ridovics, Anna

2008: A habán kerámia a 17. században. In: MıKó Árpád [ed.], Mátyás király öröksége. Késő reneszánsz művészet Magyarországon (16.-17. század). Kiállítás a Magyar Nemzeti Galériában 2008. március 28 - 2008. július 27. 2. kötet. - Budapest: Magyar Nemzeti Galéria, 2008. 87-97. (=A Magyar Nemzeti Galéria kiadványai; 2008, 4). English summary entitled: Haban Ceramics in the Seventeenth Century.

TvrDY, Josef

1912: Die Anfänge der Habaner-Keramik in Mähren [The Beginnings of the Haban Ceramics in Moravia). In: Zeitschrift für österreichische Volkskunde, XVIII. Jg, Wien 1912. 201-211.

WAWRA

1917: Sammlung Alfred Ritter Walcher v. Molthein. Deutsche Keramik des XV. bis XIX. Jahrhunderts, sowie Töpferarbeiten aus den angrenzenden slawischen Sprachgebieten [German Ceramics from the $15^{\text {th }}$ to the $19^{\text {th }}$ Century and Pottery from the Bordering Slavic Language Area]. Katalog zur 244. Kunstauktion von C. J. Wawra, Wien, Lothringerstrasse Nr. 14, Wien 1917. 


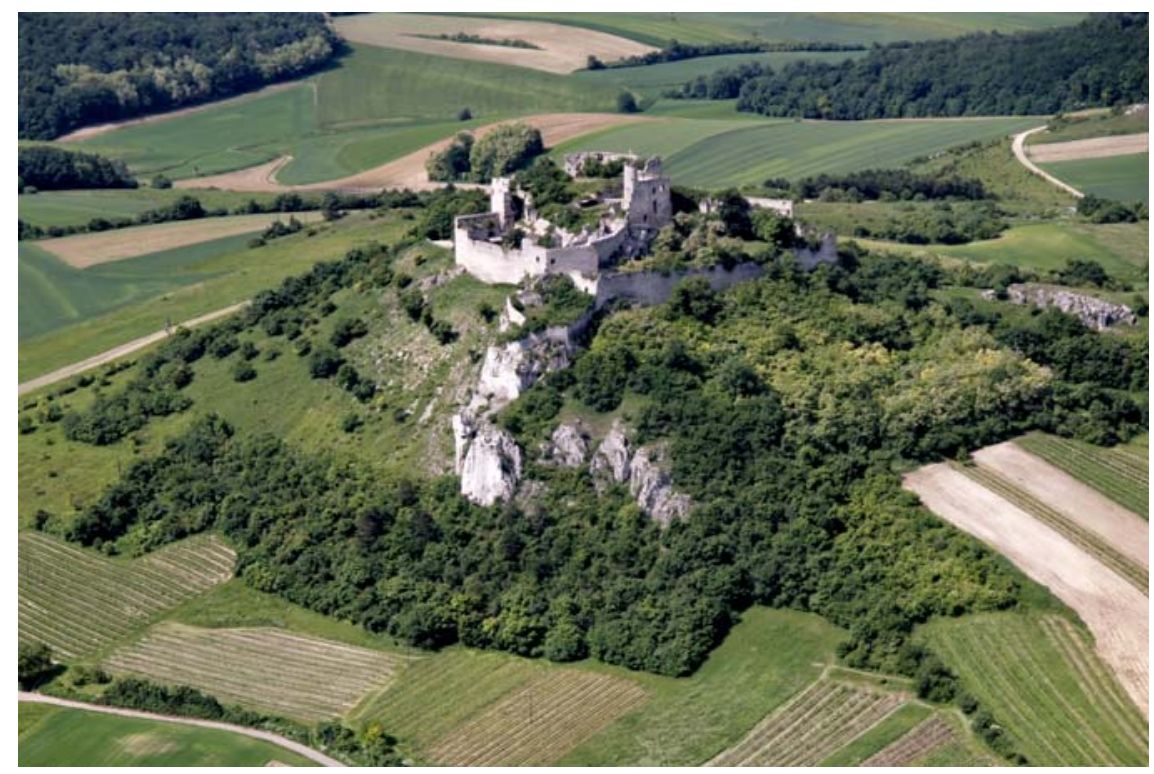

Fig. 1. Castle ruin Falkenstein in northern Lower Austria (c) by AustrianAviationArt

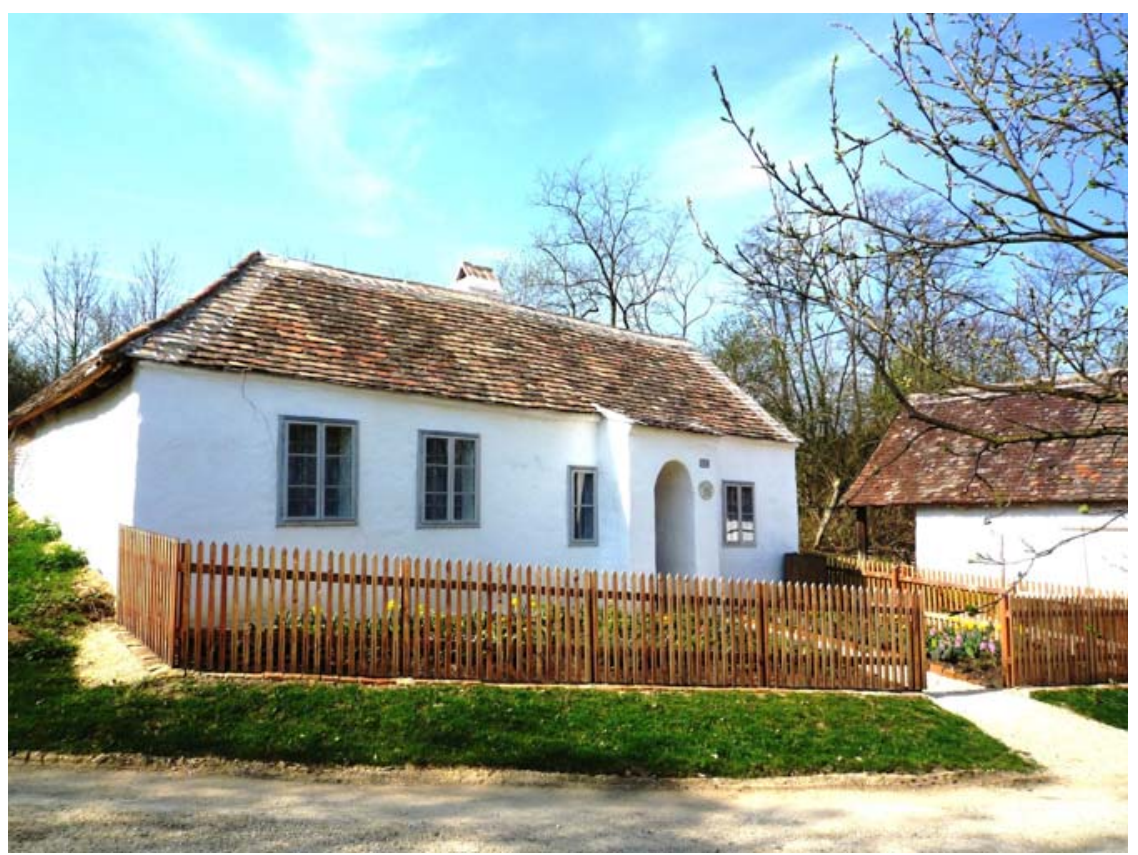

Fig. 2. Cottage in the Lower Austrian Open Air Museum Niedersulz, where an exhibition on the Anabaptists has been installed since 2008 (C) Reinhold Eichinger, Hutterischer Geschichtsverein 


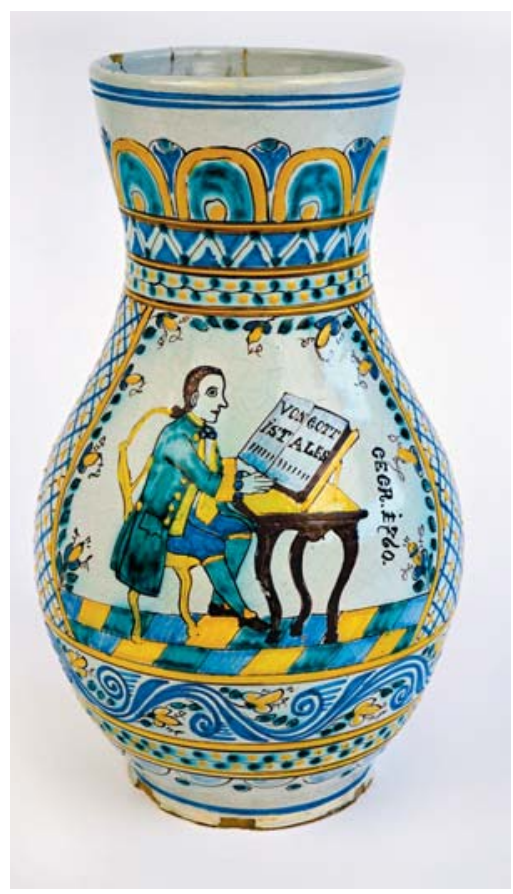

Fig. 3. Vase made by Ján Kostka, Stomfa (Stupava,Slovakia), second half of the $19^{\text {th }}$ century. Inv. n. ÖMV/83.381

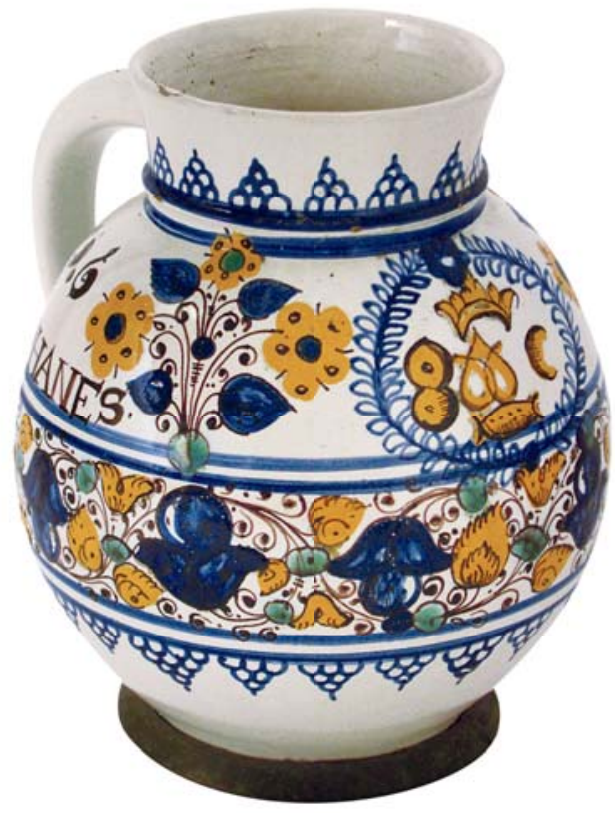

Fig. 4. 'Bäckerkrug' (Baker's jug) made for Iohanes Rath in 1660 . Inv. n. ÖMV/24.147

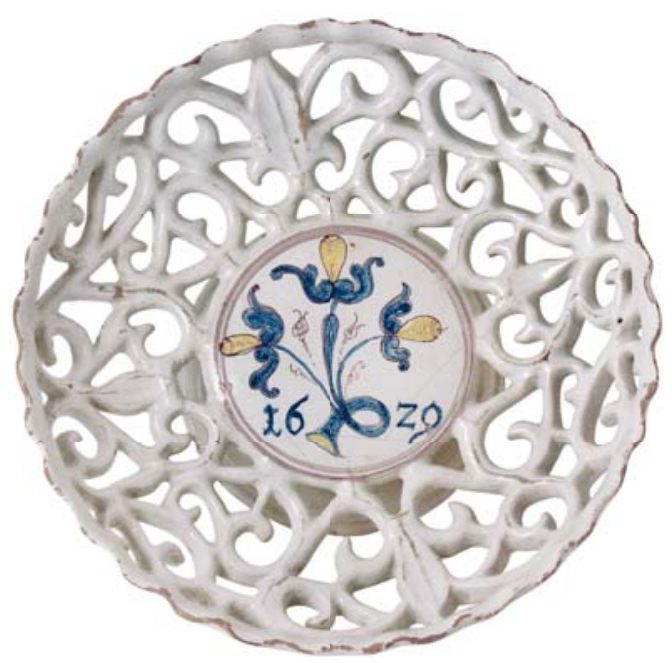

Fig. 5. Footed bowl (tazza) with perforated rim, dated 1629. Inv. n. ÖMV/36.030 


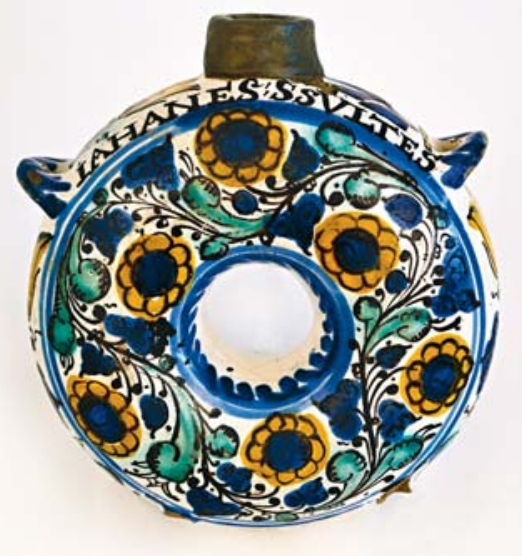

Fig. 6. Ring bottle, so-called Čutora, dated 1774 , with the trade symbols of the tailors and the inscription JAHANES SSULTES. Inv. n. ÖMV/35.992

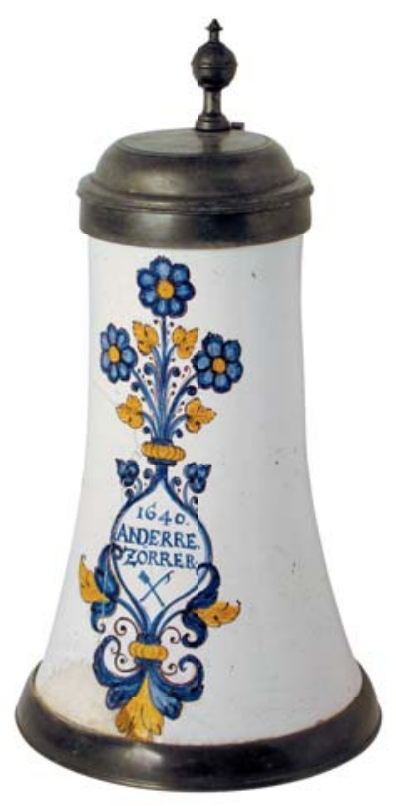

Fig. 7. Tankard with renaissance motifs from 1640 .

Inv. n. ÖMV/26.136)

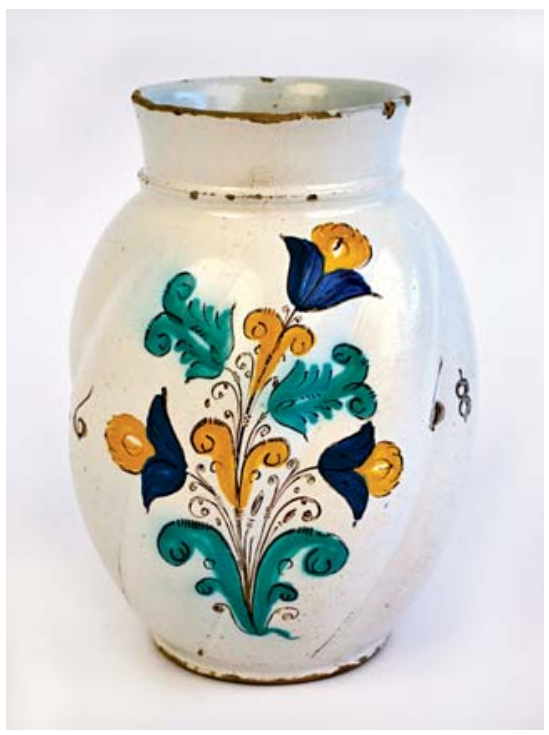

Fig. 8. Melon-shaped jug, dated 1668. Inv. n. ÖMV/31.527 


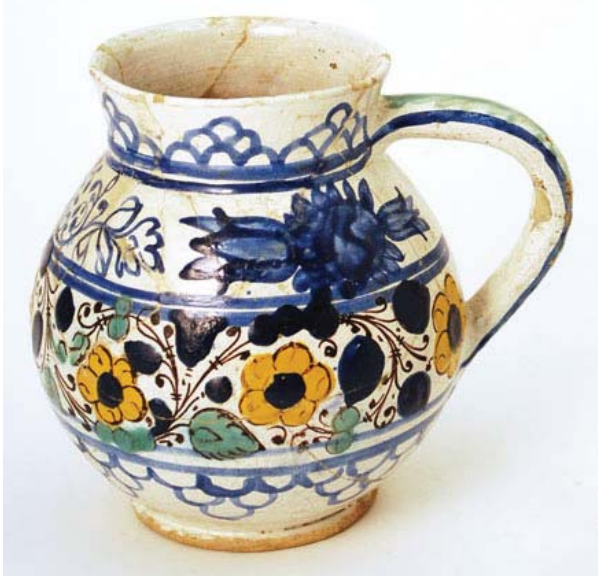

Fig. 9. Small jug, made between 1660 and 1690, Kittseer Kellerfund, probably Kosolna (Košolná, Slovakia) Inv. n. EMK/1.103

(C) Österreichisches Museum für Volkskunde, Wien / Foto: Claudia Peschel-Wacha

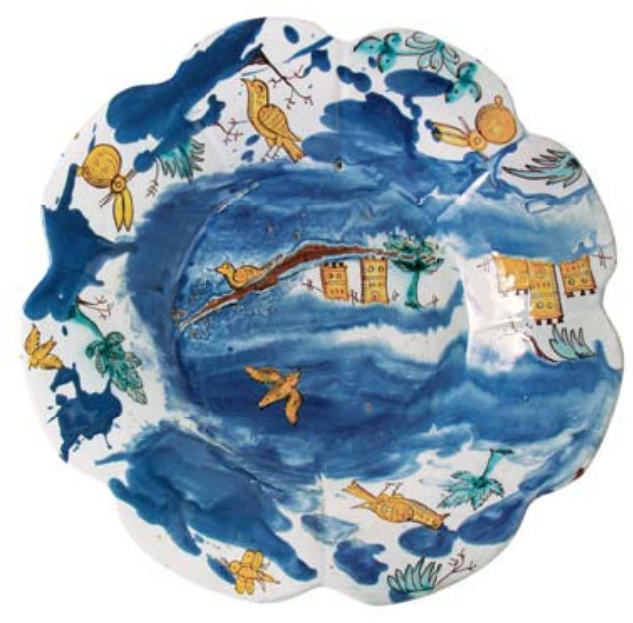

Fig. 10. Footed plate with an eight times curved edge and marbled decoration, about 1690. Inv. n. ÖMV/27.919

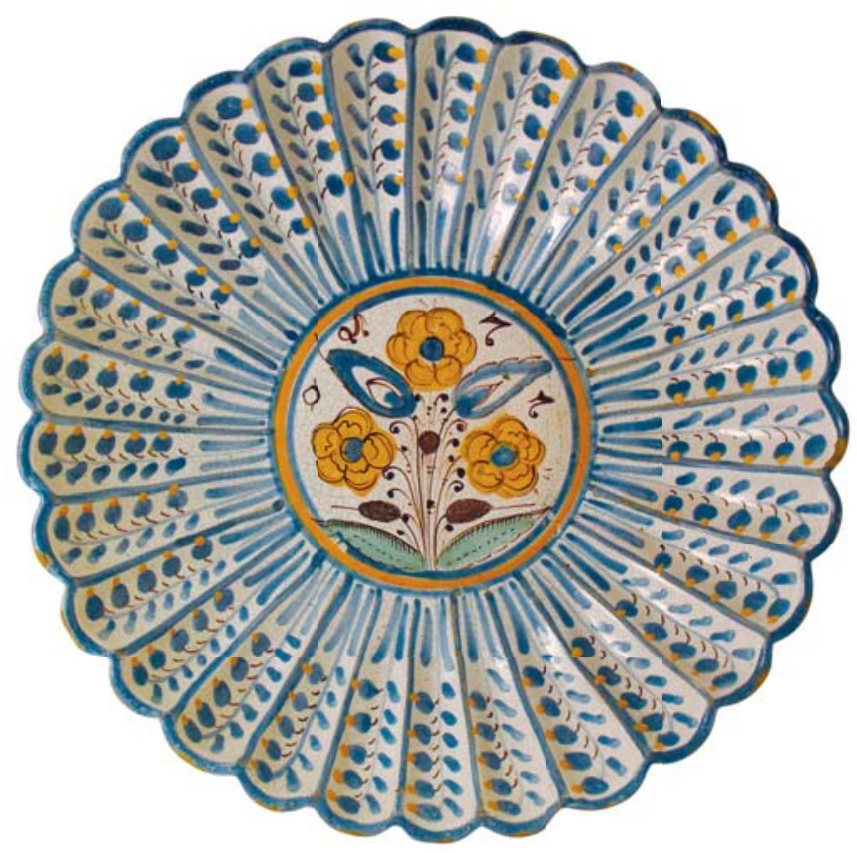

Fig. 11. Fluted bowl dated 1707 with a Lily of the Valley design. Inv. n. ÖMV/27.655 


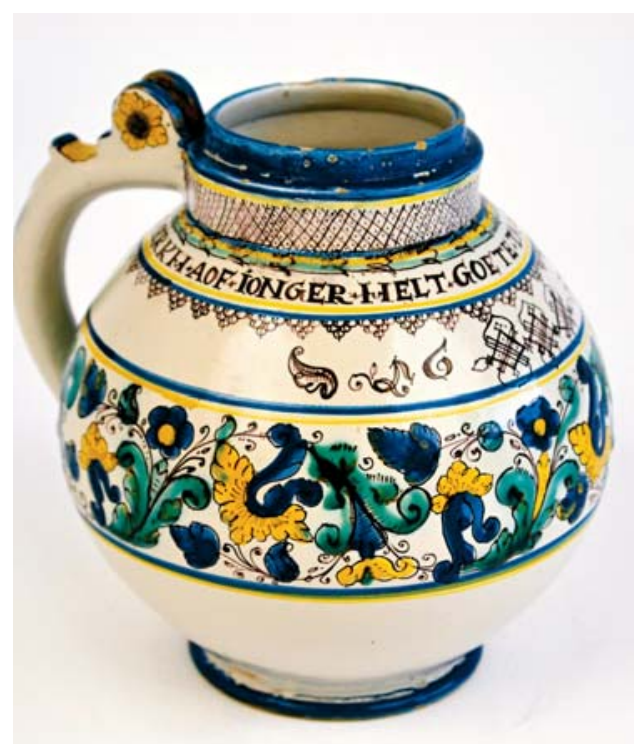

Fig. 12. Jug from 1654 with an exhorting inscription. Inv. n. ÖMV/44.071

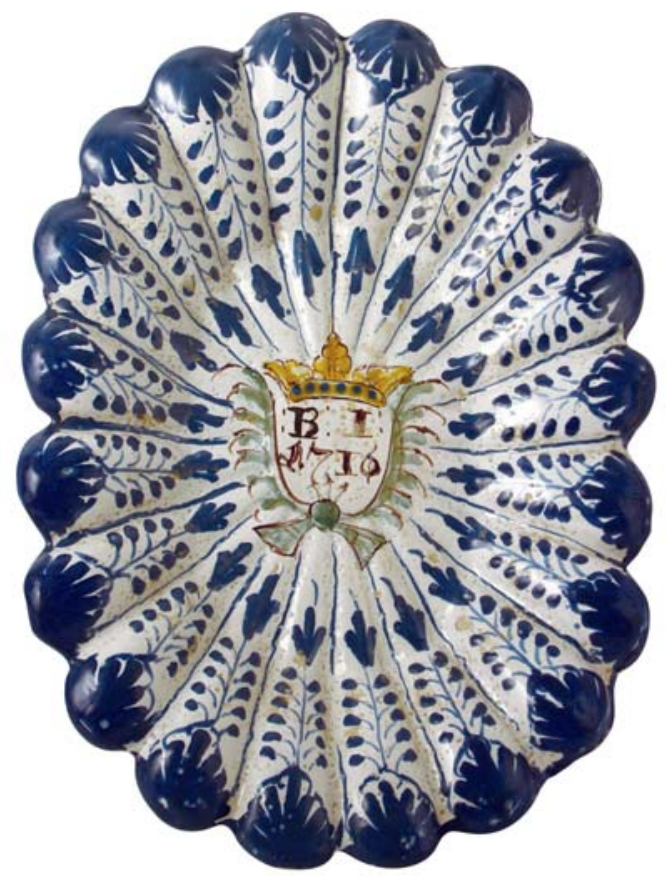

Fig. 13. Oval fluted platter on four feet with Lily of the Valleys, dated 1716. Inv. n. ÖMV/26.835 


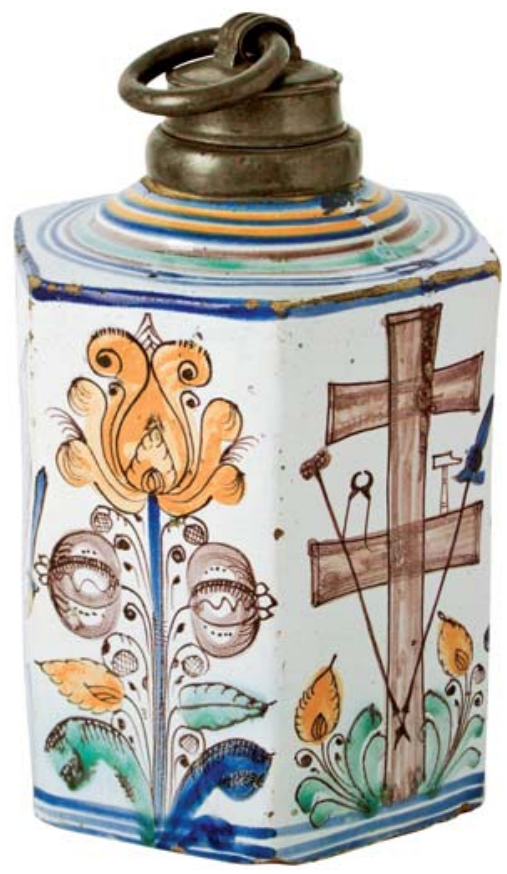

Fig. 14. Six-sided bottle from 1711 that shows a double cross and a tulip. Inv. n. ÖMV/25.263

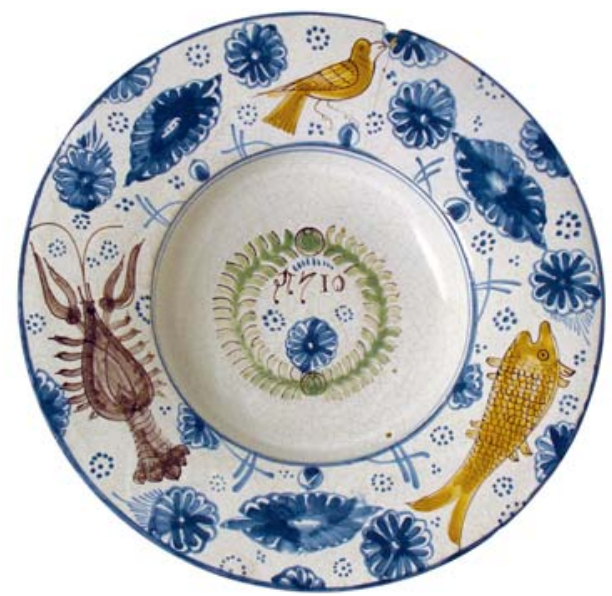

Fig. 16. Cardinal hat shaped dish, the date 1710 is written in a green wreath of leaves, probably Nagylévárd (Vel'ké Leváre, Slovakia) Inv. n. ÖMV/26.529

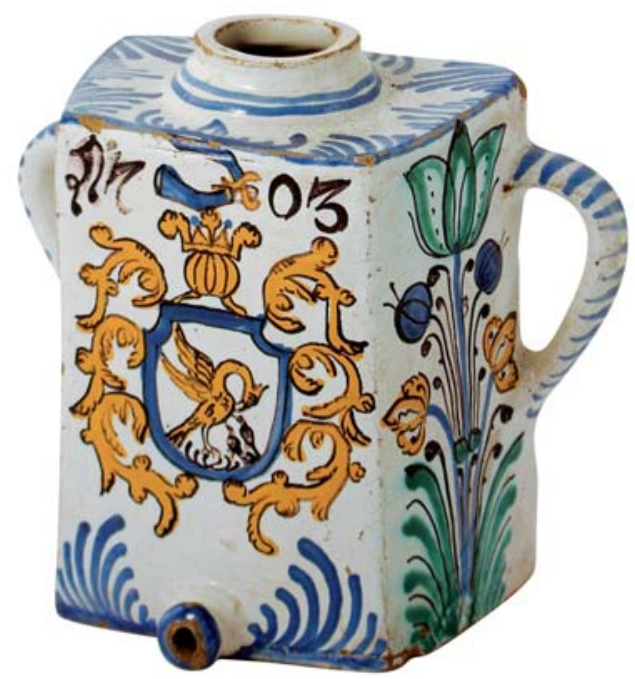

Fig. 15. Water container (fountain) from 1703 with the crest of the Batthyány family. Inv. n. ÖMV/27.660

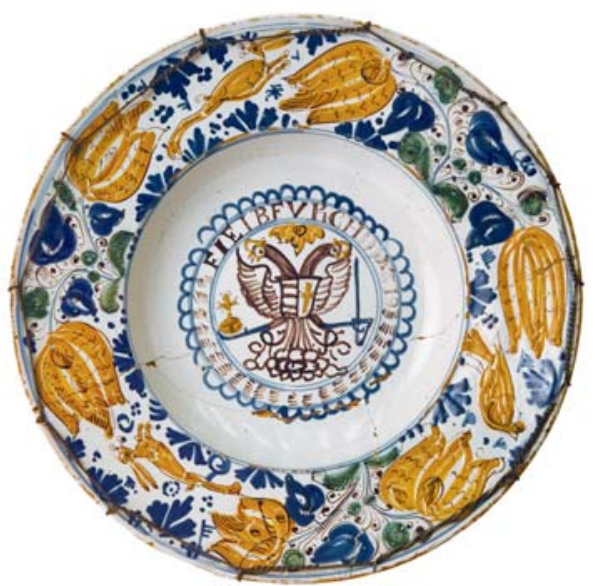

Fig. 17. Dish with the Habsburg double headed eagle in the centre of the well, dated 1719. Inv. n. ÖMV/5.933 


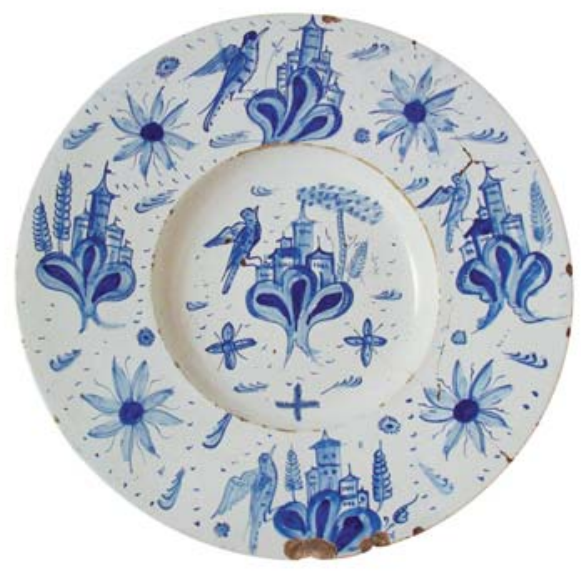

Fig. 18. Faiences in 'camaieu bleu', about 1710 to 1720 .. Inv. n. ÖMV/2.536

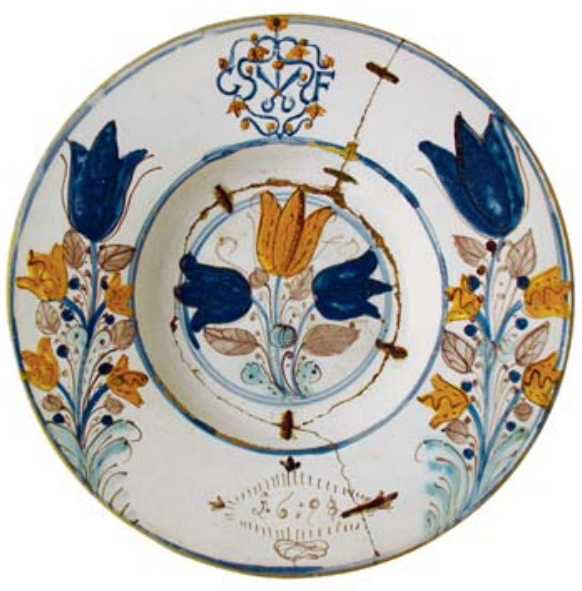

Fig. 20. Dish made for a member of the tailors guilt, dated 1698 .

Inv. n. ÖMV/31.525

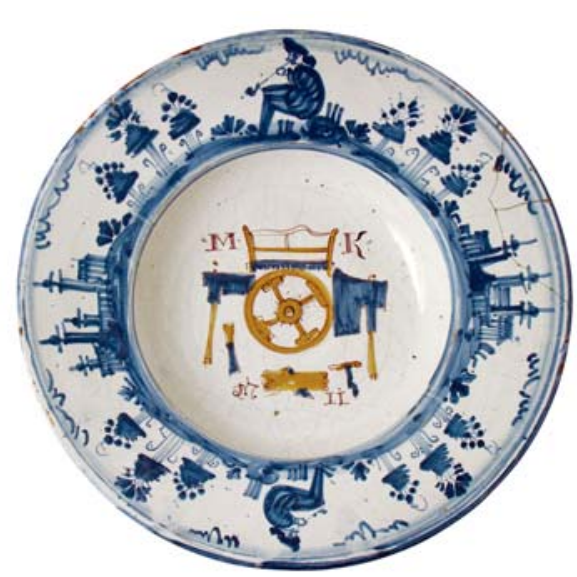

Fig. 19. Carpenter and cartwright symbols next to pipe-smoking men in the Dutch manner, dated 1711. Inv. n. ÖMV/7.809

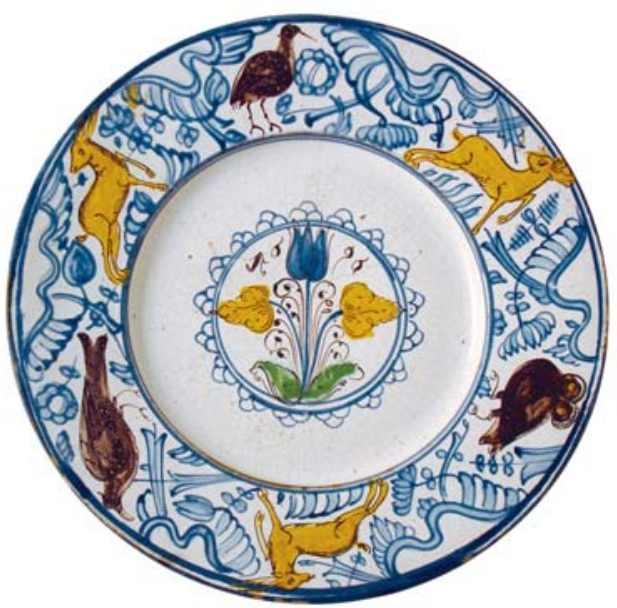

Fig. 21. Dish with birds, owl and deer, Odler workshop 1696. Inv. n. ÖMV/19.496 


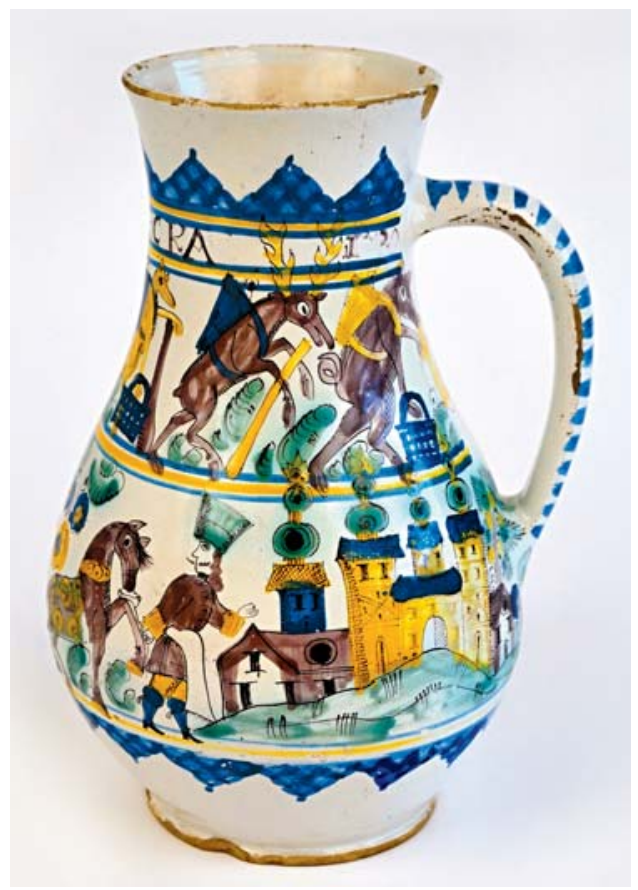

Fig. 22. Big jug with mysterious scenes from a topsyturvy world, inscribed TAMAS HRCKA 1720. Inv. n. ÖMV/44.920

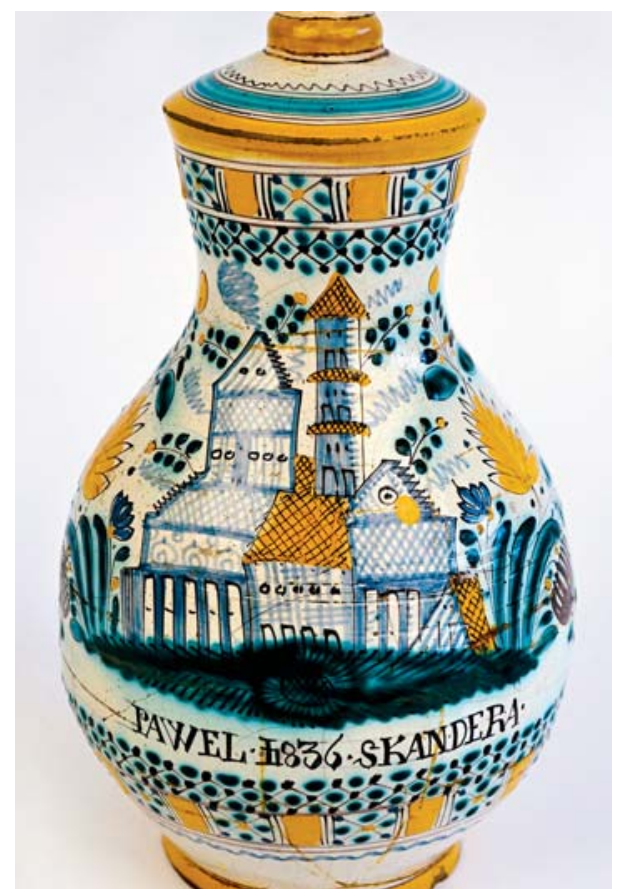

Fig. 23. Pear-shaped jug, called Eule or sova, dated 1836, from Szobotist (Sobotište, Slovakia). Inv. n. ÖMV/8.208

Figs 4, 5, 6, 7, 8, 10, 11, 13-21

(C) Österreichisches Museum für Volkskunde, Wien / Foto: Ferenc Vörösváry Figs 3, 12, 22, 23

(C) Österreichisches Museum für Volkskunde, Wien / Foto: Miroslav Slámka 
ARCHAEOLOGY 